Bulletin of the Natural History Museum, 2016, 9: 107-112.

Received 18 Sep 2016; Accepted 07 Dec 2016.

doi:10.5937/hnhmb1609107J

UDC: 597.82(497.11)

Short communication

\title{
NEW RECORDS OF FIRE-BELLIED TOAD (BOMBINA BOMBINA (LINNAEUS, 1761)) AND COMMON SPADEFOOT TOAD (PELOBATES FUSCUS (LAURENTI, 1768)) IN SERBIA
}

\author{
DANKO JOVIĆ ${ }^{1}$, RASTKO AJTIĆ ${ }^{2}$, LJILJANA TOMOVIĆ ${ }^{3}$ \\ ${ }^{1}$ Institute for Nature Conservation of Serbia, Vožda Karađorđa 14, 18000 Niš, \\ Serbia, e-mail: dankojovic@gmail.com \\ ${ }^{2}$ Institute for Nature Conservation of Serbia, Dr Ivana Ribara 91, 11070 Novi \\ Beograd, Serbia, e-mail: rastko.ajtic@zzps.rs \\ ${ }^{3}$ University of Belgrade, Faculty of Biology, Institute of Zoology, Studentski trg \\ 16, 11000 Belgrade, Serbia, e-mail: lili@bio.bg.ac.rs
}

Species' distribution data are substantial basic for future research in the areas of systematics, ecology, biogeography and especially conservation biology. Rapid worldwide declines of amphibians have emphasized a need for more precise data about their distribution at the regional and national levels, especially in countries with poor distributional data (e.g. Margules et al. 2002). Regarding both the geographical location as well as the elevation gradient, the entire territory of Serbia is inhabited by amphibians. General distribution pattern of all Serbian amphibians has been published only recently (Vukov et al. 2013), but without precise locations. As concerned to Anuras, overview of precise distribution exists for only few species, e. g. Pelobates fuscus and Pelobates syriacus (Džukić et al. 2005, 2008), while for all other species of frogs and toads in Serbia, comprehensive and detailed distribution data are not available. 
In this paper, new records of Pelobates fuscus and Bombina bombina in Serbia are presented (Fig. 1).

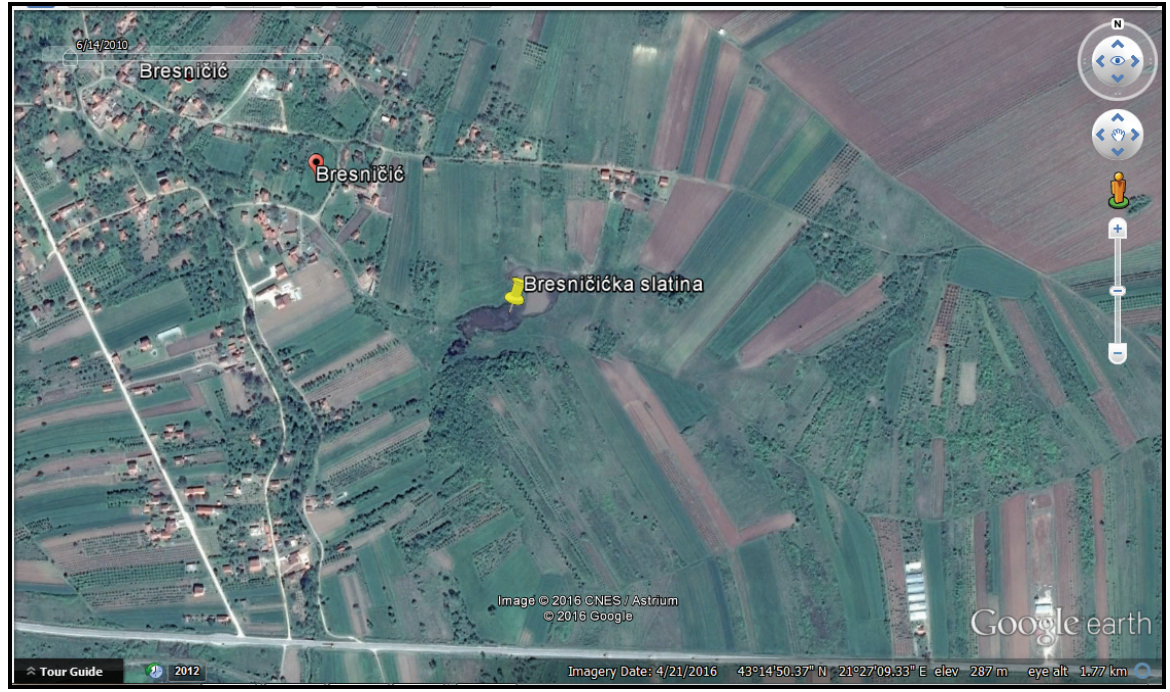

Fig. 1. - Geographic location of the founding site of Bombina bombina and Pelobates fuscus - Bresničić, central Serbia.

Bombina bombina inhabits central and eastern Europe ranging from Denmark, southern Sweden and northern Germany eastwards to the Ural Mountains of Russia, southwards to the Danube floodplain, Turkey, and the

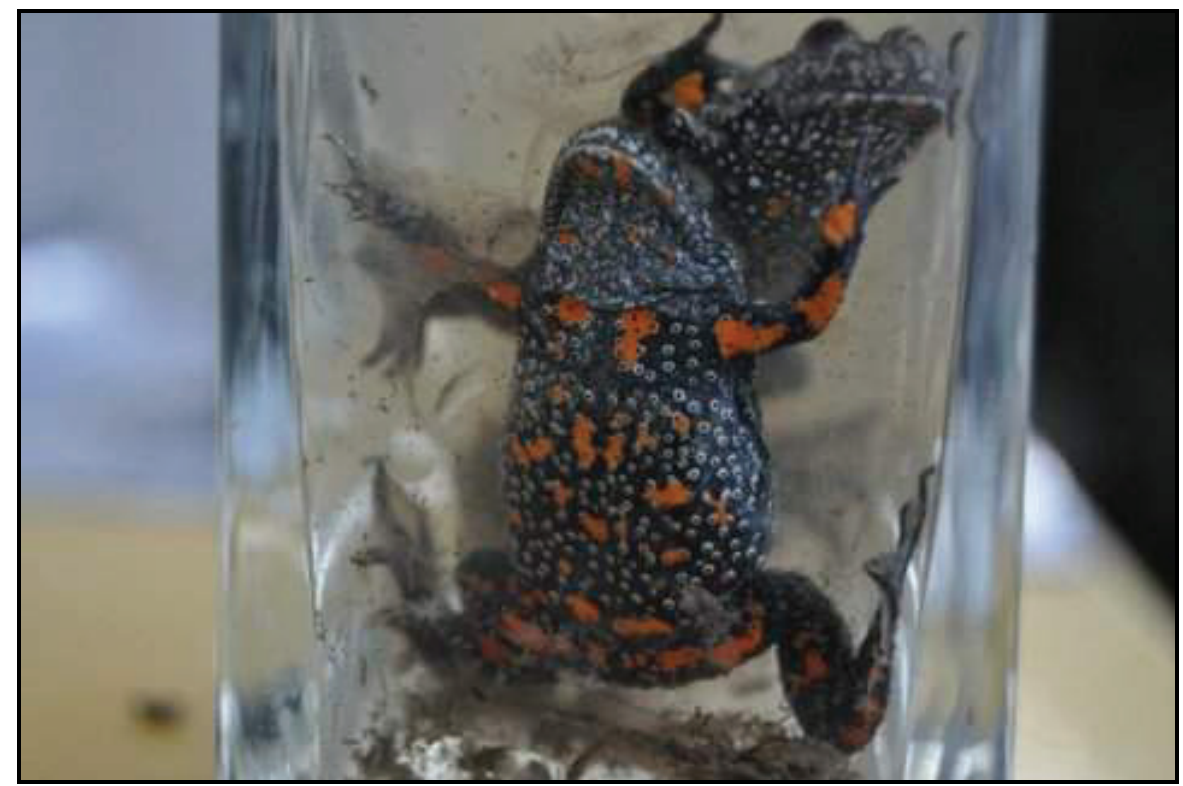

Fig. 2. - Adult specimen of Bombina bombina near Bresničić village. 
northern slopes of the Caucasus Mountains (Agasyan et al. 2009a). Pelobates fuscus is found throughout plains and hilly regions of Europe, from eastern Netherlands, eastern Belgium and eastern France, through Germany, Denmark, Sweden, central and eastern Europe to western Siberia (Russia) and northwestern Kazakhstan (Agasyan et al. 2009b). In Serbia, both species are relatively wide-spread in Pannonian part, but are quite rare in Peripannonian and Mountain-valley parts of Serbia; only few localities were recorded south of Sava and Danube rivers (Džukić et al. 2008, Vukov et al. 2013).

On May 8th 2014, near the village Bresničić (Prokuplje, central Serbia: $43.247239 \mathrm{~N}, 21.453044$ E (UTM EN38), $293 \mathrm{~m}$ a.s.1.), several adult specimens of Bombina bombina (Fig. 2) and three tadpoles of Pelobates fuscus (Fig. 3) were found in a salt pond (Fig. 4).

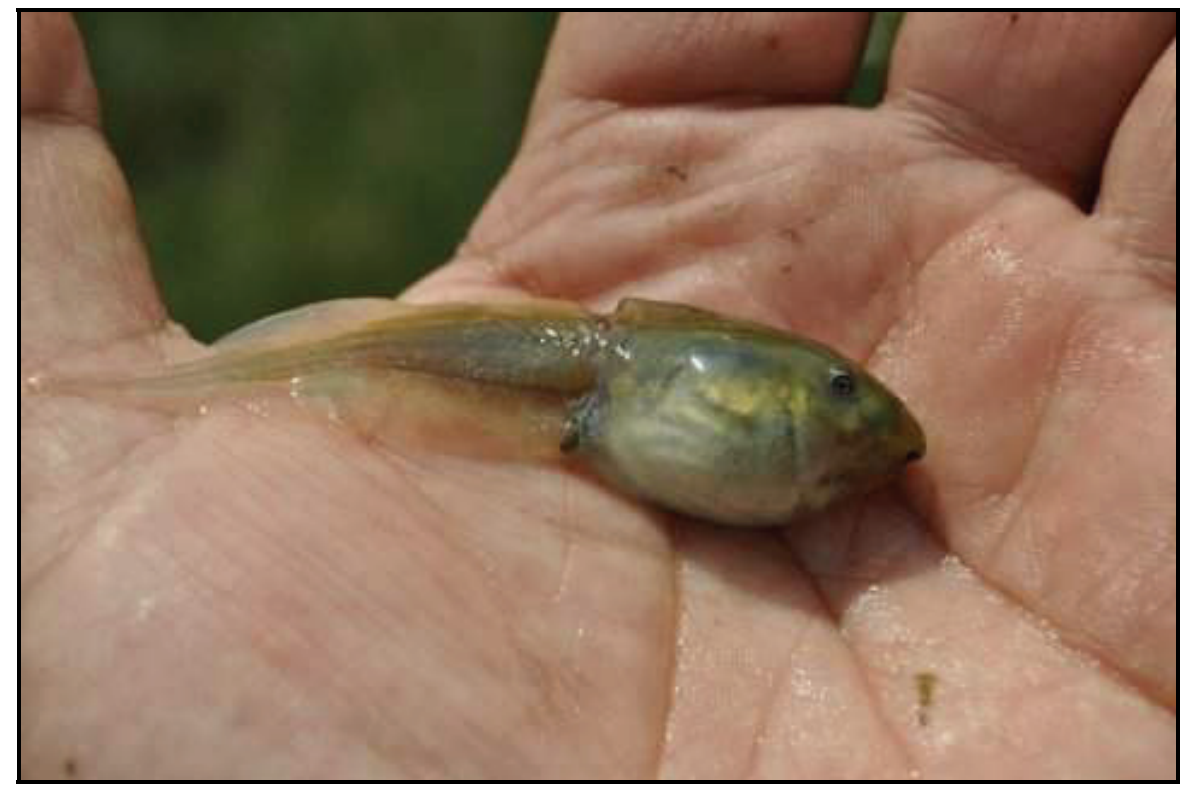

Fig. 3. -Pelobates fuscus tadpole near Bresničić village.

Syntopic species of amphibians and reptiles in the pond it's surrounding were: Lissotriton vulgaris, Hyla arborea, Pelophylax ridibundus, Emys orbicularis, Testudo hermanni, Lacerta viridis and Natrix natrix.

New records of fire-bellied toad and common spadefoot toad are filling distribution gap in the central Serbia (see: Vukov et al. 2013 - Figs. 1-2), and provide further support that both species are more frequently found in the Peripannonian and mountain-valley parts of Serbia. In addition, this locality is currently among the most southern records for both species in Serbia. Therefore, it is necessary to intensify research in other parts of Serbia where habitats are suitable for both species. 


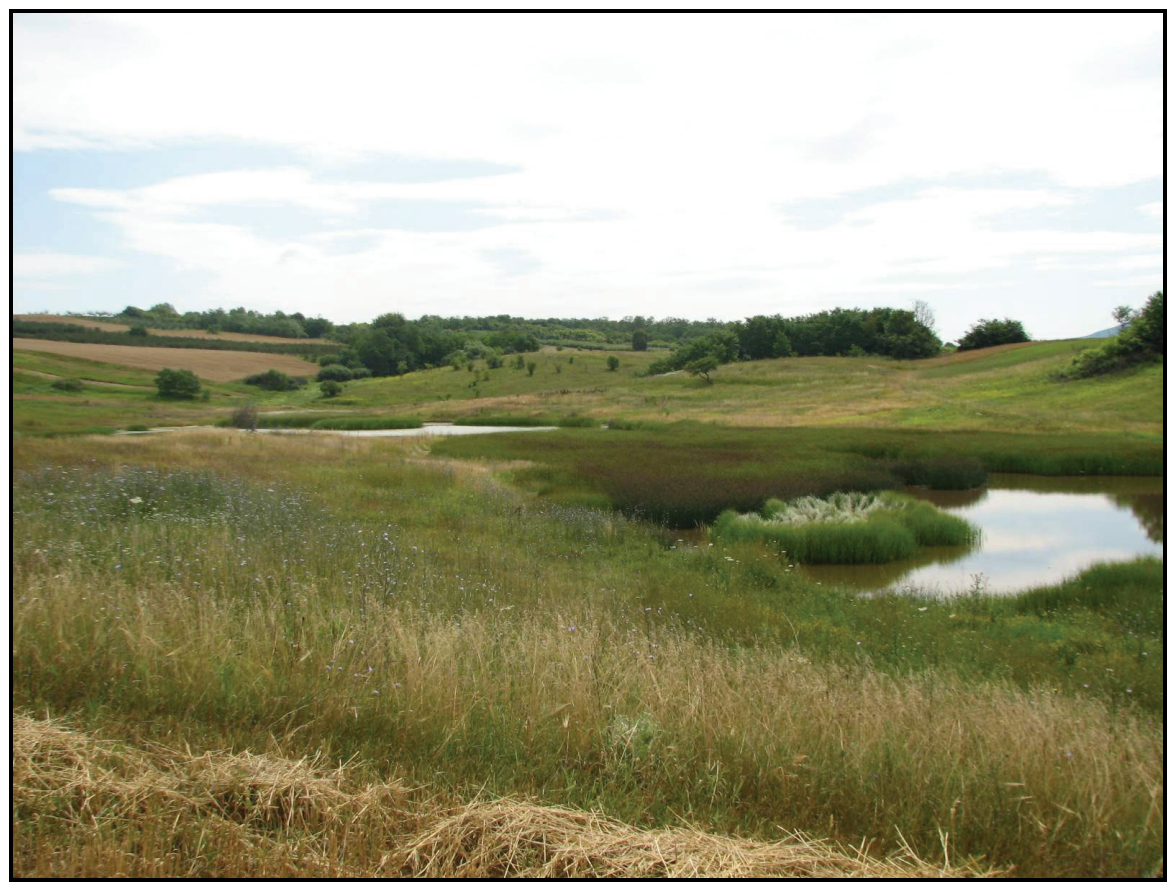

Fig. 4. - Founding site - salt pond near Bresničić village.

As concerned to conservation, both species are categorized as Least Concerned (LC) according to the IUCN Red List, with decreasing population trends in many countries (Agasyan et al. 2009a, 2009b). In Serbia, Bombina bombina and Pelobates fuscus are listed as Strictly Protected (Official Gazette of the Republic of Serbia No. 36/09). Given that population trends are not known for both species, we suggest that more comprehensive studies should be conducted in order to assess this species' population statuses and adequate conservation measures.

\section{REFERENCES}

Agasyan, A., Avisi, A., Tuniyev, B., Crnobrnja Isailović, J., Lymberakis, P., Andrén, C., Cogalniceanu, D., Wilkinson, J., Ananjeva, N., Üzüm, N., Orlov, N., Podloucky, R., Tuniyev, S., Kaya, U. (2009a): Bombina bombina. The IUCN Red List of Threatened Species 2009: e.T2865A9489517. [http://dx.doi.org/ 10.2305/IUCN.UK.2009.RLTS.T2865A9489517.en] (accessed 17 March 2016)

Agasyan, A., Avci, A., Tuniyev, B., Crnobrnja Isailović, J., Lymberakis, P., Andrén, C., Cogalniceanu, D., Wilkinson, J., Ananjeva, N., Üzüm, N., Orlov, N., Podloucky, R., Tuniyev, S., Kaya, U. (2009b): Pelobates fuscus. - The IUCN Red List of Threatened Species: e.T16498A5951455. [http://www. iucnredlist.org/details/full/16498/0] (accessed 17 March 2016) 
Džukić, G., Beškov, V., Sidorovska, V., Cogălniceanu, D. \& Kalezić, M. (2005). Historical and contemporary ranges of the spadefoot toads Pelobates spp. (Amphibia: Anura) in the Balkan Peninsula. - Acta Zoologica Cracoviensia 48A: $1-9$.

Džukić, G., Beškov, V., Sidorovska, V., Cogălniceanu, D. \& Kalezić, M. (2008) Contemporary chorology of the spadefoot toads (Pelobates spp.) in the Balkan Peninsula. - Zeitschrift für Feldherpetologie 15: 61-78.

Official Gazette of the Republic of Serbia No. 36/09: Regulation on designation and protection of strictly protected and protected wild species of plants, animals, and fungi / Službeni glasnik Republike Srbije broj 36/09: Pravilnik o proglašenju i zaštiti strogo zaštićenih i zaštićenih divljih vrsta biljaka, životinja i gljiva. - Belgrade, 2010. [In Serbian]

Vukov, T. D., Kalezić, M. L., Tomović, Lj., Krizmanić, I., Jović, D., Labus, N. \& Džukić, G. (2013): Amphibians in Serbia - distribution and diversity patterns. Bulletin of the Natural History Museum in Belgrade 6: 90-112.

\title{
НОВИ НАЛАЗИ ЦРВЕНОТРБИХ МУКАЧА (ВОМВINА ВОМВІNА (LINNAEUS, 1761)) И ОБИЧНИХ ЧЕШЫАРКИ (РЕLOBATES FUSCUS (LAURENTI, 1768)) У СРБИЈИ
}

\author{
ДАНКО ЈовИЋ
}

\section{Р Е 3 И М Е}

Подаци о дистрибуцији врста битан су основ за будућа истраживања у областима систематике, екологије, биогеографије, а посебно конзервационе биологије. Све веће опадање бројности водоземаца у свету, наглашава потребу за прецизнијим подацима о њиховој распрострањености на регионалном и националном нивоу, посебно у земљама с лошим дистрибутивним подацима (нпр Margules et al. 2002).

У погледу географског распрострањења, нагиба терена или надморске висине, цела територија Србије је насељена водоземцима.

Генерална дистрибуција водоземаца у Србији објављена је тек недавно (Vukov et al. 2013), али без прецизних локација.

У овом раду, приказани су нови налази врста Pelobates fuscus и Bombina bombina у Србији. 
Нови налази црвенотрбих мукача и обичних чешњарки, попуњавају празнину у дистрибуцији водоземаца у централној Србији (види: Vukov et al. 2013), и пружају додатну потврду, да се ове две врсте могу наћи у перипанонским просторима и долинама Србије. Осим тога, овај локалитет је тренутно међу најјужнијим тачкама у распрострањењу обе врсте у Србији. Дакле, потребно је интензивирати истраживања у другим дијеловима Србије, посебно где су станишта погодна за обе врсте. 